UDC 621.391

\title{
DETECTION OF UNKNOWN SIGNALS IN COGNITIVE RADIO NETWORKS
}

\author{
Bezruk V., Ivanenko S. \\ "Information and Network Engineering" Department, Kharkiv National University of \\ Radio Electronics, Ukraine
}

Background. At this stage of the development of wireless technologies, there is a rapid growth in the volume of information services, as well as the speed of information transfer. To meet these needs, additional frequency bands should be used. However, at the moment most of the radio spectrum is already occupied for use. To solve this problem, the concept of cognitive radio can be used, the effectiveness of which mostly depends on the algorithms for detecting signals in frequency channels.

Objective. The aim of the work is to investigate algorithms for detecting unknown signals during radio monitoring in cognitive radio networks.

Methods. Investigation of algorithms for detecting unknown signals was carried out by the method of statistical tests.

Results. The quality of detection of unknown signals is investigated. The proposed detection algorithms should increase the detection efficiency of unoccupied frequency channels, and thereby improve the functioning of cognitive radio networks.

Conclusions. The work deals with nonclassical methods of detecting unknown signals, the application of which is possible within the framework of the concept of cognitive radio. These methods differ from the classical ones in that they use information only about noise. As a result of computer research, estimates of the detection quality of unknown signals were obtained. These estimates confirm the operability and the possibility of using the proposed algorithms in radio monitoring in cognitive radio networks.

Keywords: cognitive radio; methods of signal detection; unknown radio signals; radio monitoring; radio spectrum; frequency resource; unknown signals.

\section{Introduction}

At present, wireless radio technologies using a frequency resource are widely introduced. The current number of users of the frequency resource is steadily growing and the frequency range is quite crowded. However, the analysis shows that the efficiency of the frequency resource usage is low [1], that limits the introduction of new wireless radio technologies.

One of the solutions to this problem was the emergence of the IEEE 802.22 standard which determines the operation of radio systems in the frequency range from $54 \mathrm{MHz}$ to $698 \mathrm{MHz}$. This standard is based on the use of the cognitive radio (CD) system [2-6]. This searches for "spectral holes," that is, portions of the frequency range which are not currently used by primary (licensed) users and provision to secondary users.

For example, a large frequency band has been allocated for the broadcasting services, some of which are not used at times and can be provided for communication with the purpose of collecting data from various sensors of utilities and security systems, personnel alert systems in hospitals, etc. The main task of the CD system is to monitor the dynamics of changes in the signal-interference situation while radio monitoring the specified frequency range. This means fixing the following signal situations, which are added to each interval of observation time in the analyzed frequency channels:

1. No signals are observed which were observed earlier. Such a situation may be a sign of a change in the dislocation or decommissioning of systems emitting these signals in this frequency channel.

2. There were new, but previously known signals. Naturally, this is a sign of the appearance of the radiating system, which previously was operated in this frequency channel.

3. There are new unknown signals, which can serve as a sign of the work of new, previously unknown systems.

Obtaining information about the use of a frequency resource can be performed in two ways [2]:

- from the database of the cognitive radio system;

- by radio monitoring the specified frequency range. The main methods of processing the information obtained with radio monitoring can be classified as follows:

- detecting the radiation of the heterodyne of the receiving device of the primary user (cooperative method); 
- detection of the emissions of the transmitting device of the primary user (non-cooperative method),

- determination of the level of interference.

To identify unoccupied frequency channels, an analysis of the signal-interference situation in the frequency channels must be carried out. As a result, a decision is taken on the effect of either a mixture of the interfered signal or only interference in the frequency channel being analyzed, which in fact is the task of detecting the signal against a background of interference.

It should be noted that during radio monitoring, signals and interference in frequency channels are, as a rule, random in nature for various reasons. Therefore, it becomes necessary to solve the problems of detecting random signals against a background of random interference. In this case, there is the a priori uncertainty about the probabilistic characteristics of signals and interference.

The following signal detection methods are known in these conditions [2]:

- energy method;

- method of consistent filtration;

- method of the cycle-stationary function.

These detection methods are based on the use of certain information about the signal.

The energy method is the most common, due to its low computational complexity and ease of implementation. The main disadvantage is its low suitability for detecting signals with a small signal-tointerference ratio, as well as the difficulty in determining the required trigger threshold, considering the constantly changing signal and interference conditions in the frequency channels.

The advantage of the method of consistent filtering is a short observation time to obtain the required level of false alarm or signal skip. The disadvantages include the need to use a certain type of receiving device to receive signals from each class of primary users. This makes this method impractical for wide application in cognitive radio networks.

The method of using the cycle-stationary function is based on the original redundancy inherent in the signal. The advantage of the method is that it is able to distinguish the detectable signal from interference quite well. This is possible even if the useful signal is below the noise level. The drawbacks of the method include large computational complexity and a considerable time of observation.

Methods for detecting signals under conditions of the a priori uncertainty are also known, which is overcome with the use of appropriate training samples of realizations [7]. However, the peculiarity of the detection of signals in radio monitoring is the lack of the possibility of obtaining training samples of signals due to the diversity of signals in the frequency channels. This limits the use of these methods of detecting signals during radio monitoring.

In this article, we consider non-traditional methods for detecting unknown signals, which are based only on knowledge of the probabilistic properties of interference in the frequency channels being analyzed $[8,9]$. Investigations of the detection characteristics for the relevant decision rules were made by statistical tests on samples of real signal realizations and interference received by automated radio monitoring.

\section{Decisive rules for detecting unknown signals}

When processing observations in the analyzed frequency channels, two hypotheses are put forward:

$H^{1}: x(t)=S(t)+\xi(t)-$ a useful signal acts against the background of the interference;

$H^{0}: x(t)=0+\xi(t)$ - there is only interference.

For the problem of detecting the known signals against a given noise, the decision rule based on comparing the likelihood ratio with a certain threshold value can be used [7]. The a priori uncertainty that occurs during radio monitoring is overcome using training samples that are used to obtain estimates of unknown parameters of signal distribution and interference densities. However, the specificity of real detection tasks for radio monitoring is such that unknown signals are received for processing, for which it is not possible to obtain training samples. Under these conditions, known methods for detecting signals under conditions of the a priori uncertainty can not be used. Therefore, the need arises to solve non-traditional problems of detecting unknown signals against the background of known interference acting in the analyzed frequency channels.

In work [9], methods for detecting unknown signals against a noise background specified in a probabilistic sense are proposed. In order to detect unknown signals in the analyzed frequency channel, the following decision rule can be used:

$$
H^{1}: \quad W\left(\vec{X} / \vec{\alpha}^{0}\right)<\lambda
$$

- the hypothesis of a signal is assumed;

$$
H^{0}: W\left(\vec{X} / \vec{\alpha}^{0}\right)>\lambda
$$

- the hypothesis of a signal is rejected.

$W\left(\vec{X} / \vec{\alpha}^{0}\right)$ - the multidimensional distribution density of the interference represented by the $L$ - -dimensional discrete sample vector $\vec{X}, \vec{\alpha}^{0}$ - the distribution density 
parameter, $\lambda-$ is a certain threshold value determined from the condition for providing a given false alarm probability.

Taking into account the analytical formula for the Gaussian distribution of the observation vector $\vec{X}$ the decision rule (1) is reduced to a comparison with the threshold of the mahalanobis distance of the vector $\vec{X}$ to the standard $\vec{\mu}^{0}$ :

$$
\begin{aligned}
& H^{1}:\left(\vec{X}-\vec{\mu}^{0}\right)^{\operatorname{tr}}\left(R^{0}\right)^{-1}\left(\vec{X}-\vec{\mu}^{0}\right)>\Delta, \\
& H^{0}:\left(\vec{X}-\vec{\mu}^{0}\right)^{t r}\left(R^{0}\right)^{-1}\left(\vec{X}-\vec{\mu}^{0}\right) \leq \Delta .
\end{aligned}
$$

Here $\vec{\mu}^{0}, R^{0}$ are the estimates of the mean vector and the correlation matrix obtained from the training sample of the interference implementations;

$\Delta-$ is a certain threshold value.

When choosing the Karunen-Loeve basis, we obtain the decisive rule (2) in the form of the relations:

$$
H^{1}: \sum_{j=1}^{N} \frac{\left(c_{j}-\mu_{j c}^{0}\right)^{2}}{\left(\sigma_{j c}^{0}\right)^{2}}>\Delta_{c}^{0} ; \quad H^{0}: \sum_{j=1}^{N} \frac{\left(c_{j}-\mu_{j c}^{0}\right)^{2}}{\left(\sigma_{j c}^{0}\right)^{2}} \leq \Delta_{c}^{0}
$$

$\left(\sigma_{j c}^{0}\right)^{2}=\lambda_{j^{-}}$the eigenvalues of the sample interference correlation matrix $R^{0}, \vec{c}$ - Representation of realizations $\vec{X}$ in the Karunen-Loeve basis with dimension $N<L$.

In the case of representing observations $\vec{X}$ in a harmonic basis, a decision rule of the type (3) can be used, where $c_{j}$ - these are the spectral samples of observations in the basis of discrete exponential functions (DEF).

If the decision is made according to the sample by the volume $v$ of realizations $\vec{X}_{v}$, the decision rule (3) takes the following form:

$$
\begin{gathered}
H^{1}: \sum_{r=1}^{v} \sum_{j=1}^{N} \frac{\left(c_{j}-\mu_{j c}^{0}\right)^{2}}{\left(\sigma_{j c}^{0}\right)^{2}}>\Delta_{c v}^{0} ; \\
H^{0}: \sum_{r=1}^{v} \sum_{j=1}^{N} \frac{\left(c_{j}-\mu_{j c}^{0}\right)^{2}}{\left(\sigma_{j c}^{0}\right)^{2}} \leq \Delta_{c v}^{0} .
\end{gathered}
$$

If observations are presented in the form of a set of co-ordinates of energy spectra, a decision rule based on comparison of the Euclidean distances of the current estimates of the energy spectrum of observations to the standard can be used:

$$
H^{1}: \sum_{j=1}^{N}\left(G_{j}-G_{j c}^{0}\right)^{2}>\Delta_{G} ; H^{0}: \sum_{j=1}^{N}\left(G_{j}-G_{j}^{0}\right)^{2} \leq \Delta_{G} .
$$

Here the standards $G_{j}^{0}=\frac{1}{n_{0}} \sum_{r=1}^{n_{0}}\left(c_{j r}^{0}-\mu_{j c}^{0}\right)^{2}, j=\overline{1, N}$ - these are estimates of the coordinates of the energy spectrum of the interference, found from the training sample by the volume $\mathrm{n}_{0}$ of realizations; $G_{j}=\frac{1}{v} \sum_{r=1}^{v}\left(c_{j r}-\mu_{j c}^{0}\right)^{2}, j=\overline{1, N}$ - current estimate of the energy spectrum of the observation, obtained from a sample of a smaller volume $v<<\mathrm{n}_{0}$.

The above decision rules (2) - (5) define some possible algorithms for detecting unknown signals against a background of interference that can be used to identify unoccupied frequency channels in cognitive radio networks.

\section{Results of the investigation of algorithms for detecting unknown signals}

Since the efficiency of cognitive radio networks largely depends on the efficiency of detecting unoccupied frequency channels in the analyzed frequency range, comparative studies of the considered decision rules for signal detection were conducted. The studies were performed by the method of statistical tests using samples of realizations of real signals and interference that were obtained during radio monitoring of a given frequency range. As a result, the estimates were obtained for the quality of detection of signals for different decision rules under different conditions and parameters of the studies.

To conduct research using the method of statistical testing, the considered decisive detection rules (2) - (5) are implemented in the MATLAB software environment. The studies were carried out on samples of signals and interference corresponding to radio emission in the frequency band, which are specified in the IEEE 802.22 standard for the operation of cognitive radio networks. Digital recordings of signal and interference implementations were obtained using SDR (Software Defined Radio) equipment that allows scanning and analysis of a given frequency range, as well as digital recording of observations in the selected frequency channels.

A special feature of SDR equipment is the formation and use of digital signals at an intermediate frequency (digital IF) for the operation of reprogrammed frequency filtering devices. The use of a digital IF was made possible by the appearance of high-speed ADCs and DACs with high bit and high linearity, as well as digital signal processing devices based on high-speed signal processors [10]. 
As a SDR receiver, a DVB-T TV USB tuner was used, with the installation and configuration of the corresponding software, in particular, the SDR \# open source program. Such a tuner is capable to provide the radio emissions receiving in the frequency bands from $24 \mathrm{MHz}$ to $1710 \mathrm{MHz}$ and analyzing the spectra of signals with different types of modulations: AM, FM, WFM, NFM, CW, SSB. In Fig. 1 the shape of the spectrum of one of the signals with broadband frequency modulation is shown. This signal was considered in the studies as an unknown signal that appears against the background of interference in the analyzed frequency channel.

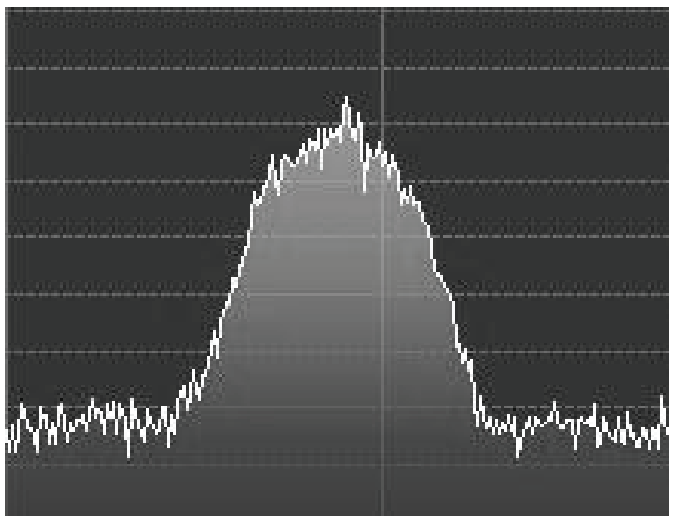

Fig. 1. Spectrum of a signal with broadband frequency modulation

Using this equipment and software, training and control samples of interference implementations and some signals operating in frequency channels according to the IEEE 802.22 standard were received and recorded digitized. The training samples of the interference implementations are used to estimate the parameters of the decision rules (2) - (5). Control samples of signals and interference are used to conduct statistical tests and obtain estimates of the probabilities of correct detection of unknown signals and the probabilities of false alarm. To obtain estimates of the quality of signal detection by statistical tests, control samples of signal realizations and interference with a volume of 1000 realizations with a duration of $L=512$ time samples were used.

As a result of the research, the dependencies of the probability of correct detection of an unknown signal $P(1 / 1)$ from the signal-to-noise ratio (SNR) in terms of power for a fixed false alarm probability $P(1 / 0)$ were obtained. In Fig. 2 such dependencies are given for the decision rule (4) in the representation of observations in the basis of the DEF, the fixed probability of false alarm and the different number of implementations on which the decision was made.

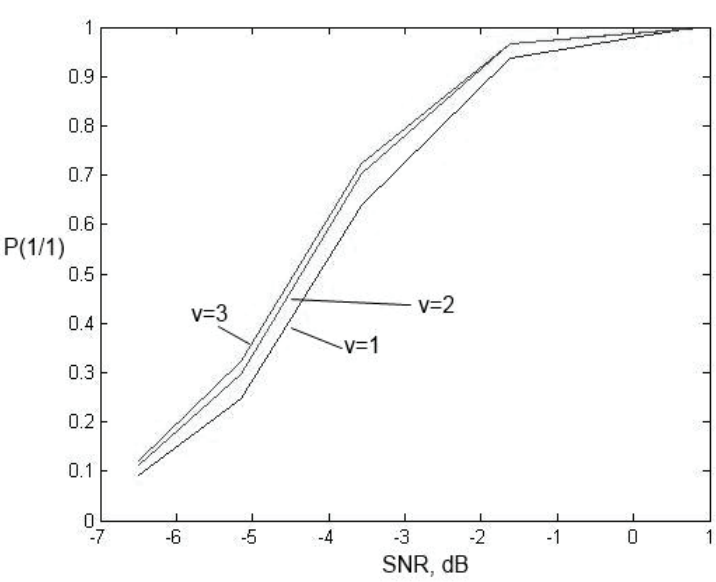

Fig. 2. Dependence of the probability of correct detection of signals from SNR for the decision rule (4) (for $\mathrm{P}(1 / 0)=0,04$ and different $v)$

It is seen that an increase in the probability of a correct detection of an unknown signal can be ensured both with increasing SNR and with the number of implementations required for processing.

For this decisive rule, the dependencies of the correct signal detection on the probability of false alarm for different SNRs are also obtained (Fig. 3). These dependencies show how the values of these quality indicators can be exchanged among themselves.

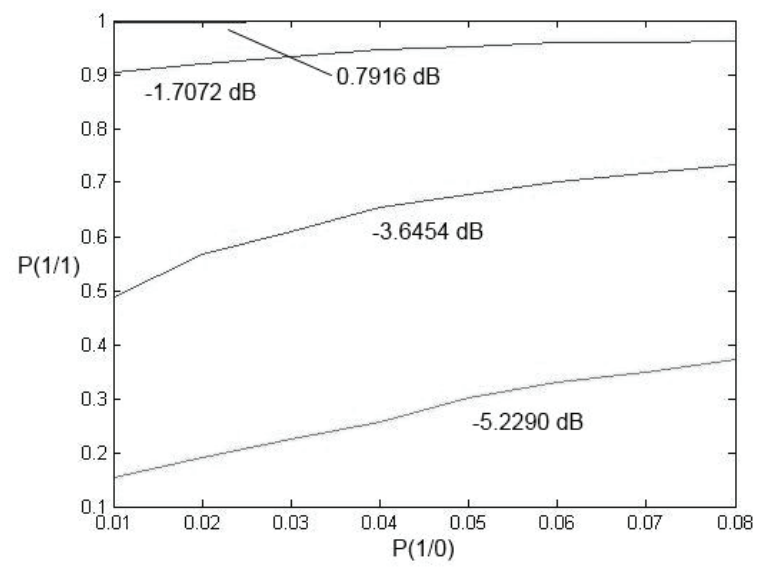

Fig. 3. Dependence of the probability of correct detection of a signal on the probability of false alarm for the decision rule (4) (for different SNRs and $v=1$ )

Similar dependences were obtained for the decisive rule for detecting signals (5) for the case of representing observations by estimating the coordinates of the energy spectra of observations in the basis of the DEF. In this case, different volumes of samples of realizations were used, according to which the current 
estimates of the energy spectrum were located (Fig. 4, Fig. 5).

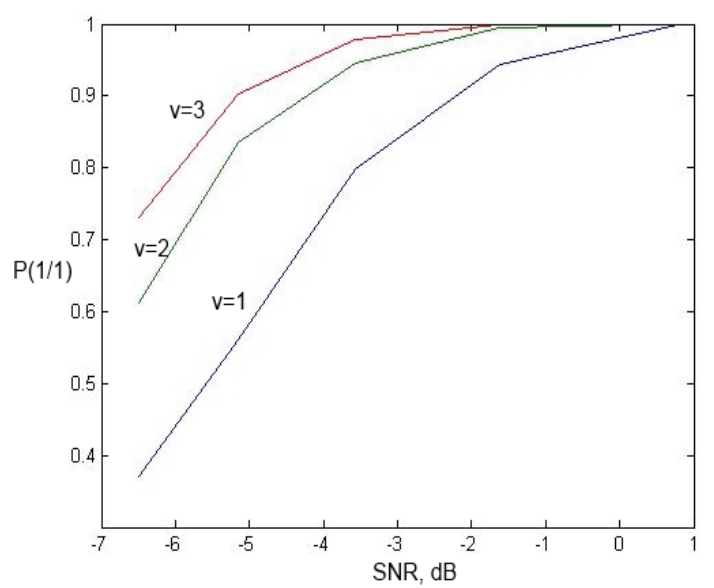

Fig. 4. Dependence of the probability of correct detection from SNR for the decision rule (5) (for $\mathrm{P}(1 / 0)=0,04$ )

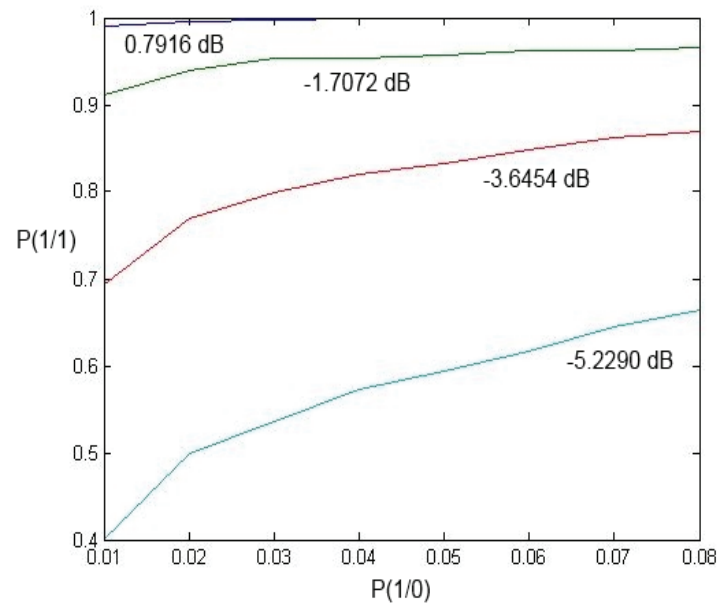

Fig. 5. Dependence of the probability of correct detection on the probability of false alarm for the decision rule (5) (for different SNRs, $\mathrm{P}(1 / 0)=0,04 \quad v=1)$

It can be seen that the improvement in the quality of detection is achieved not only with the improvement of SNR, but also with the increase in the sample size of implementations for decision making. In addition, comparing the obtained results of signal detection for the decision rules (4) and (5), it can be concluded that the decision rule (5) has a higher probability of correct detection while other things are equal.

The dependences displayed on Fig. 2 - Fig. 5 are obtained from samples of signal realizations which spectrum is shown in Fig. 1. The studies were also conducted on the samples of other signals which are typical of cognitive radio networks. During the studies, these signals were considered as unknown signals acting in a frequency channel against a background of interference with a given training sample. At the same time, acceptable characteristics for detecting unknown signals have also been obtained, which generally confirms the operability of the proposed algorithms for detecting unknown signals and gives grounds for recommending them for solving practical radio monitoring problems in cognitive radio networks.

\section{Conclusions}

1. The main features of the radio monitoring within the framework of the concept of cognitive radio have been considered. The main advantages and disadvantages of existing methods for detecting unknown signals in the analyzed frequency channels have been determined.

2. A variant of overcoming the a priori uncertainty arising during radio frequency monitoring of the frequency range is proposed, which consists in using non-classical methods for detecting signals based on the use of information only about interference.

3. Different decisive rules for detecting unknown signals acting against a background of interference in frequency channels and presented by their training samples have been considered, which are used to estimate unknown parameters of decision rules.

4. Investigations of detection algorithms by statistical tests on samples of real signals and interference, that correspond to radio waves, used in the work of cognitive radio networks, have been carried out.

5. As a result of the research, estimates of detection quality indicators were obtained which confirm the operability of the considered algorithms for detecting unknown signals and give grounds to recommend them for the usage in radio monitoring in cognitive radio networks.

\section{References}

1. Register of assignments of radio frequencies (centralized assignments) [Electronic resource] // UCRF Access mode: http://www.ucrf.gov.ua/

2. Ž. Tabaković, "A Survey of Cognitive Radio Systems" [Electronic resource] // A Survey of Cognitive Radio Systems - Access mode: https://www.fer.hr/_download/repository/KDI Tabakovic Ze ljko.pdf

3. B. Wild, K. Ramchandran, "Detecting Primary Receivers for Cognitive Radio Applications", in Proc. of IEEE International Symposium on New Frontiers in Dynamic Spectrum Access Networks (DySPAN 2005), pp. 124-130.

4. S. Haykin, "Cognitive Radio: Brain-empowered Wireless Communications", IEEE Journal on Selected Areas in Commun., Vol. 23, No. 2, February 2005, pp. 201-220. 
5. D. Cabric, S. M. Mishra and R. Brodersen, "Implementation Issues in Spectrum Sensing for Cognitive Radios", Conference Record of the 38th Conference on Signals, Systems and Computers, November 2004, pp. $772-776$.

6. S. M. Mishra, A. Sahai and R. Brodersen, "Cooperative Sensing Among Cognitive Radios", in Proc. of IEEE International Conference (ICC 2006), June 2006, pp. 1658-1663.

7. Theory of signal detection / P.S. Akimov, P.A. Bakut, V.A. Bogdanovich et al .; Ed. P.A. Bakuta. M .: Radio and Communication, 1984. 440 p.
8. Omelchenko, V.A. Fundamentals of the spectral theory of signal recognition. - Kharkov: High school, 1983. - 156s.

9. Bezruk V.M., Pevtsov G.V. Theoretical bases of designing systems for recognition of signals for automated radio control. - Kharkov: Collegium, 2007. - 430 p.

10. SDR And CR Boost Wireless Communications // www.electronicdesign.com.

Received in final form on November 20, 2017

\section{Безрук В.М., Іваненко С.А.}

Виявлення невідомих сигналів в когнітивних радіомережах.

Проблематика. На данному етапі розвитку бездротових технологій спостерігається стрімкий зріст об'ємів інформаційних послуг, а також швидкості передачі інформації. Щоб задовільніти ці потреби, слід використовувати додаткові смуги частот. Однак, на даний момент більша частина радіоспектру вже зайнята для використання. Для вирішення цієї проблеми може бути використана концепція когнітивного радіо, ефективність використання якої в значній мірі залежить від алгоритмів виявлення сигналів в частотних каналах.

Мета. Метою роботи є дослідження алгоритмів виявлення невідомих сигналів під час радіомоніторінгу у когнітивних радіомережах.

Методи. Дослідження алгоритмів виявлення невідомих сигналів проведено методом статистичних випробувань.

Результати. Досліджені показники якості виявлення невідомих сигналів. Запропоновані алгоритми виявлення мають підвищити ефективність виявлення незайнятих частотних каналів, і тим самим поліпшити функціонування когнітивних радіомереж.

Висновки. У роботі розглянуті некласичні методи виявлення невідомих сигналів, застосування яких можливо у рамках концепції когнітивного радіо. Ці методи відрізняються від класичних тим, що вони використовують інформацію лише про шум. В результаті комп'ютерного дослідження були отримані оцінки показників якості виявлення невідомих сигналів. Ці оцінки підтверджують працездатність та можливість використання запропонованих алгоритмів під час радіомоніторингу у когнітивних радіомережах.

Ключові слова: когнітивне радіо; методи виявлення сигналів; невідомі радіосигнали; радіоспектр; радіомоніторинг; частотний ресурс; невідомі сигнали.

\section{Безрук В.М., Иваненко С.А.}

Обнаружение неизвестных сигналов в когнитивных радиосетях.

Проблематика. На данном этапе развития беспроводных технологий наблюдается стремительный рост объемов информационных услуг, а также скорости передачи информации. Для обеспечения этих потребностей, следует использовать дополнительные полосы частот. Однако, на данный момент большая часть радиоспектра уже занята для использования. Для решения этой проблемы может быть использована концепция когнитивного радио, эффективность использования которой в значительной степени зависит от алгоритмов обнаружения сигналов в частотных каналах.

Цель. Целью работы является исследование алгоритмов обнаружения неизвестных сигналов во время радиомониторинга в когнитивных радиосетях.

Методы. Исследование алгоритмов обнаружения неизвестных сигналов проведено методом статистических испытаний.

Результаты. Исследованы показатели качества обнаружения неизвестных сигналов. Предложенные алгоритмы обнаружения должны повысить эффективность обнаружения незанятых частотных каналов, и тем самым улучшить функционирование когнитивных радиосетей.

Выводы. В работе рассмотрены неклассические методы выявления неизвестных сигналов, применение которых возможно в рамках концепции когнитивного радио. Эти методы отличаются от классических тем, что они используют информацию только о шуме. В результате компьютерного исследования были получены оценки показателей качества обнаружения неизвестных сигналов. Эти оценки подтверждают работоспособность и возможность использования предложенных алгоритмов при проведении радиомониторинга в когнитивных радиосетях.

Ключевые слова: когнитивное радио; методы обнаружения сигналов; неизвестные радиосигналы; радиомониторинг; радиоспектр; частотный ресурс; неизвестные сигналы. 